Article

\title{
Biobased Contents of Natural Rubber Model Compound and Its Separated Constituents
}

\author{
Masao Kunioka ${ }^{1, *}$, Kazuhiro Taguchi ${ }^{1}$, Fumi Ninomiya ${ }^{1}$, Mari Nakajima ${ }^{2}$, Akira Saito ${ }^{2}$ \\ and Shunji Araki ${ }^{2}$
}

1 National Institute of Advanced Industrial Science and Technology (AIST), Higashi 1-1-1, Tsukuba, Ibaraki 305-8565, Japan; E-Mails: taguchi-kazuhiro@aist.go.jp (K.T.); f.ninomiya@aist.go.jp (F.N.)

2 The Japan Rubber Manufacturers Association (JRMA), Motoakasaka 1-5-26, Minato-ku, Tokyo 107-0051, Japan; E-Mails: nakaji-m@bridgestone.co.jp (M.N.); saito.ad@om.asahi-kasei.co.jp (A.S.); araki-s@bridgestone.co.jp (S.A.)

* Author to whom correspondence should be addressed; E-Mail: m.kunioka@aist.go.jp; Tel.: +81-29-861-4584; Fax: +81-29-861-4576.

Received: 30 December 2013 / Accepted: 7 February 2014 / Published: 10 February 2014

\begin{abstract}
Production of rubber products with biobased constituents from biomass resources is desirable for conserving our planet's limited resources and preventing global warming. Herein, a natural rubber model compound was produced to determine the biobased contents as per various indices for calculating the amount of biomass resources used in rubber products. The biobased mass and biobased carbon contents of the natural rubber model compound were $38.7 \%$ and $39.2 \%$, respectively, which were calculated from the feed amounts of the constituents as per the International Organization for Standardization (ISO)/the draft of International Standard (DIS) 16620-2 and 16620-4. The model compound was separated into its constituents such as polymer, additive, carbon black, and zinc oxide using ISO 1407, 4650, 7720-2, and 9924-3. The biobased carbon content of this model compound was $37.6 \%$, calculated from the percent of modern carbon $(p \mathrm{MC})$, which was measured directly using accelerator mass spectrometry (AMS). The calculated values for this model compound agreed with those calculated from the feed amounts of the constituents. Thus, it was confirmed that these calculation and determination methods of the biobased mass and the biobased carbon contents for rubber products should be published as new ISO international standards after a discussion at technical committee 45, "rubber and rubber products" to evaluate rubber products with larger biobased contents of natural rubber and other biobased ingredients.
\end{abstract}


Keywords: biobased content; biobased mass content; biobased carbon content; rubber product; accelerator mass spectrometry; ISO 16620

\section{Introduction}

During the early periods of the rubber industry, only natural rubber was used for manufacturing rubber products. Eventually, many types of synthetic rubber such as styrene-butadiene rubber were developed using petroleum resources. In 2005, 58\% of global rubber production (21 million tons) used synthetic rubber, which could meet the performance requirements of many types of rubber products.

However, to reduce the use of petroleum, which is a nonrenewable resource, and global warming, by reducing $\mathrm{CO}_{2}$ emissions, it is important to change the source of rubber products from petroleum to biomass, which is sustainable. To achieve this goal, it is necessary that not only the amount of natural rubber should be increased, but also that synthetic rubbers should be developed from biomass-based monomers. Microbial production of isoprene has been reported [1,2]. From such biobased isoprene monomers, polyisoprene could be produced as biobased synthetic rubber. In addition, resources for natural rubber are being diversified. Natural rubber is produced from latex, which is excreted from the rubber tree (Hevea brasiliensis) - a plantation crop in South Asia. The production of natural rubber from Russian dandelion (Taraxacum kok-saghyz) and Guayule (Parthenium argentatum), which can grow in regions of the world, is also being developed [3,4].

The carbon content of rubber products is high; thus, rubber product waste such as scrap tires can be used in thermal recycling as fuel for a boiler because of its high energy of combustion. In Japan in $2012,58 \%$ of scrap tires ( 1 million tons) were used in thermal recycling [5]. In these cases, $\mathrm{CO}_{2}$ emitted from the biobased constituents of rubber products during combustion does not increase the amount of $\mathrm{CO}_{2}$ in the atmosphere, because this emitted $\mathrm{CO}_{2}$ was fixed by photosynthesis during the growth of plants as biomass resource (the concept of "zero emission"). The content of biomass fuels such as wood pellets or agricultural wastes (e.g., bagasse) in the fuel used in an incinerator or a boiler can be evaluated on the basis of the International Organization for Standardization (ISO) 13833 [6].

Approximately half of the rubber content of present-day rubber products such as automobile tires comprises fossil-based synthetic rubber, whose ratio is dependent on the product grade or production company, as indicated in Figure 1 [5]. Biomass-based additives such as oil or filler are being developed by many companies. A fossil-fuel-free tire has been developed [7]. Large-sized tires used in buses, trucks, and airplanes include a large amount of natural rubber, primarily because of the sufficient mechanical properties of natural rubber. To promote the use of biobased constituents, a reliable index for the amount of biomass resource used is necessary. 
Figure 1. Composition of main materials used in automobile tires in Japan in 2012 [5].

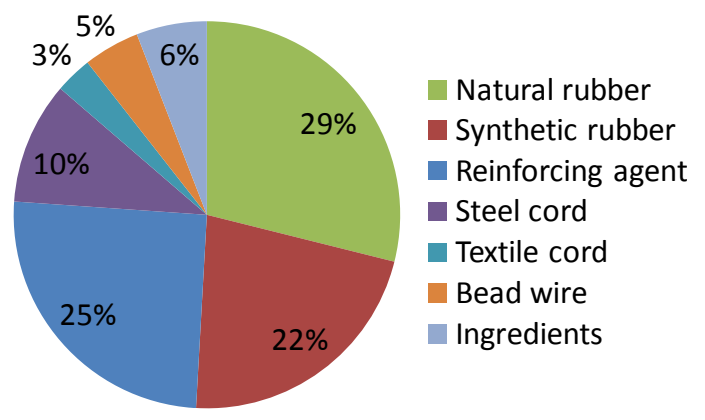

Almost all the organic constituents of plastic products are fossil-based. To regulate biobased plastic products, some international standards have been developed for the determination of the biobased content (Table 1). American Society for Testing and Materials (ASTM) D6866 was the first published method for determining the biobased content in 2004. Conité Européen de Normalisation (CEN) 16137 was published in 2011. Recently, ISO 16620 series for determination of biobased content was discussed in ISO technical committee (TC) 61 "Plastics". International standards proposed by Japan define four types of biobased contents (Table 2). These standards will be published soon. Quantification of the biobased content based on the carbon mass $\left(M_{X}\right)$ of the biobased constituents can be calculated as the biobased carbon content in the total organic carbon $\left(x_{\mathrm{B}}^{\mathrm{TOC}}\right)$ or the biobased carbon content in the total carbon $\left(x_{\mathrm{B}}^{\mathrm{TC}}\right)$. The method based on the mass $\left(W_{X}\right)$ of the biobased synthetic polymer and biobased constituents can be calculated as the biobased synthetic polymer content $\left(m_{\mathrm{BSP}}\right)$ and the biobased mass content $\left(m_{\mathrm{B}}\right)$, respectively. Natural rubber is a natural polymer and not a biobased synthetic polymer, so natural rubber products may not be evaluated by ISO 16620-3, where they are defined as biobased synthetic polymer content. It is very important to select the optimal index from the four types of biobased content depending on the intended purpose of the rubber product. Comparing different types of biobased contents is meaningless.

Table 1. International standards that define biobased contents.

\begin{tabular}{|c|c|c|}
\hline \multirow{2}{*}{ Organization } & \multicolumn{2}{|r|}{ Standard } \\
\hline & NO & Title \\
\hline $\begin{array}{l}\text { American Society for Testing } \\
\text { and Materials (ASTM) }\end{array}$ & ASTM D 6866-12 & $\begin{array}{l}\text { Standard test method for determining biobased content of } \\
\text { solid, liquid, and gaseous samples using radiocarbon } \\
\text { analysis }\end{array}$ \\
\hline Conité Européen de & $\mathrm{CEN} / \mathrm{TS}$ & Plastics-determination of biobased carbon content \\
\hline Normalisation (CEN) & 16137:2011 & \\
\hline \multirow{4}{*}{$\begin{array}{l}\text { International Organization for } \\
\quad \text { Standardization (ISO) }\end{array}$} & $\begin{array}{l}\text { ISO/DIS 16620-1 } \\
\text { published soon }\end{array}$ & Plastics-biobased content_-Part 1 General principles \\
\hline & $\begin{array}{c}\text { ISO/DIS } 16620-2 \\
\text { published soon }\end{array}$ & $\begin{array}{l}\text { Plastics-biobased content-Part } 2 \text { Determination of } \\
\text { biobased carbon content }\end{array}$ \\
\hline & $\begin{array}{l}\text { ISO/DIS 16620-3 } \\
\text { published soon }\end{array}$ & $\begin{array}{l}\text { Plastics-biobased content-Part } 3 \text { Determination of } \\
\text { biobased synthetic polymer content }\end{array}$ \\
\hline & $\begin{array}{l}\text { ISO/WD 16620-4 } \\
\text { under discussion }\end{array}$ & $\begin{array}{l}\text { Plastics-biobased content-Part } 4 \text { Determination of } \\
\text { biobased mass content }\end{array}$ \\
\hline
\end{tabular}


Several mark certification systems have been developed for biobased products using these biobased contents (Table 3). Using these systems, consumers can recognize whether these products are biobased and what is the amount of biobased constituents in these products. Solvent-separation methods for determining the biobased synthetic polymer content and biobased mass content of the constituents of plastic products are currently being developed $[8,9]$.

Table 2. Biobased content in plastic products ${ }^{1, *}$.

\begin{tabular}{|c|c|c|c|}
\hline Biobased content & Definition & Calculation $^{2, *}$ & $\begin{array}{c}\text { International } \\
\text { standard } \\
\end{array}$ \\
\hline $\begin{array}{l}\text { Biobased carbon } \\
\text { content to total } \\
\text { organic carbon (TOC) }\end{array}$ & $\begin{array}{l}\text { Amount of carbon derived from } \\
\text { biomass present in the product }\end{array}$ & $x_{\mathrm{B}}^{\mathrm{TOC}}=100 \frac{M_{\mathrm{A}}+M_{\mathrm{C}}+M_{\mathrm{D}}}{M_{\mathrm{A}}+M_{\mathrm{B}}+M_{\mathrm{C}}+M_{\mathrm{D}}+M_{\mathrm{E}}}$ & $\begin{array}{c}\text { ASTM D6866 } \\
\text { CEN/TS } 16137 \\
\text { ISO 16620-2 }\end{array}$ \\
\hline $\begin{array}{l}\text { Biobased carbon } \\
\text { content to total } \\
\text { carbon (TC) }\end{array}$ & $\begin{array}{l}\text { Amount of carbon derived from } \\
\text { biomass present in the product }\end{array}$ & $x_{\mathrm{B}}^{\mathrm{TC}}=100 \frac{M_{\mathrm{A}}+M_{\mathrm{C}}+M_{\mathrm{D}}}{M_{\mathrm{A}}+M_{\mathrm{B}}+M_{\mathrm{C}}+M_{\mathrm{D}}+M_{\mathrm{E}}+M_{\mathrm{F}}}$ & $\begin{array}{c}\text { CEN/TS } 16137 \\
\text { ISO 16620-2 }\end{array}$ \\
\hline $\begin{array}{c}\text { Biobased synthetic } \\
\text { polymer content }\end{array}$ & $\begin{array}{l}\text { Amount of biobased synthetic } \\
\text { polymer present in the product }\end{array}$ & $m_{\mathrm{BSP}}=100 \frac{W_{\mathrm{A}}}{W_{\mathrm{A}}+W_{\mathrm{B}}+W_{\mathrm{C}}+W_{\mathrm{D}}+W_{\mathrm{E}}+W_{\mathrm{F}}}$ & ISO 16620-3 \\
\hline $\begin{array}{l}\text { Biobased mass } \\
\text { content }\end{array}$ & $\begin{array}{l}\text { Amount of biobased synthetic } \\
\text { polymer, natural polymer, and } \\
\text { biobased additives in the product }\end{array}$ & $m_{\mathrm{B}}=100 \frac{W_{\mathrm{A}}+W_{\mathrm{C}}+W_{\mathrm{D}}}{W_{\mathrm{A}}+W_{\mathrm{B}}+W_{\mathrm{C}}+W_{\mathrm{D}}+W_{\mathrm{E}}+W_{\mathrm{F}}}$ & ISO 16620-4 \\
\hline
\end{tabular}

Notes: ${ }^{1, *}$ Constituents in plastic products: A, biobased synthetic polymer; B, fossil-based polymer; C, natural polymer; $\mathrm{D}$, biobased additive; E, fossil-based additive; F, Inorganic additive; ${ }^{2, *} M_{X}$, mass of carbon in X constituent; $W_{X}$, mass of $\mathrm{X}$ constituent.

Table 3. Mark certification system using biobased content.

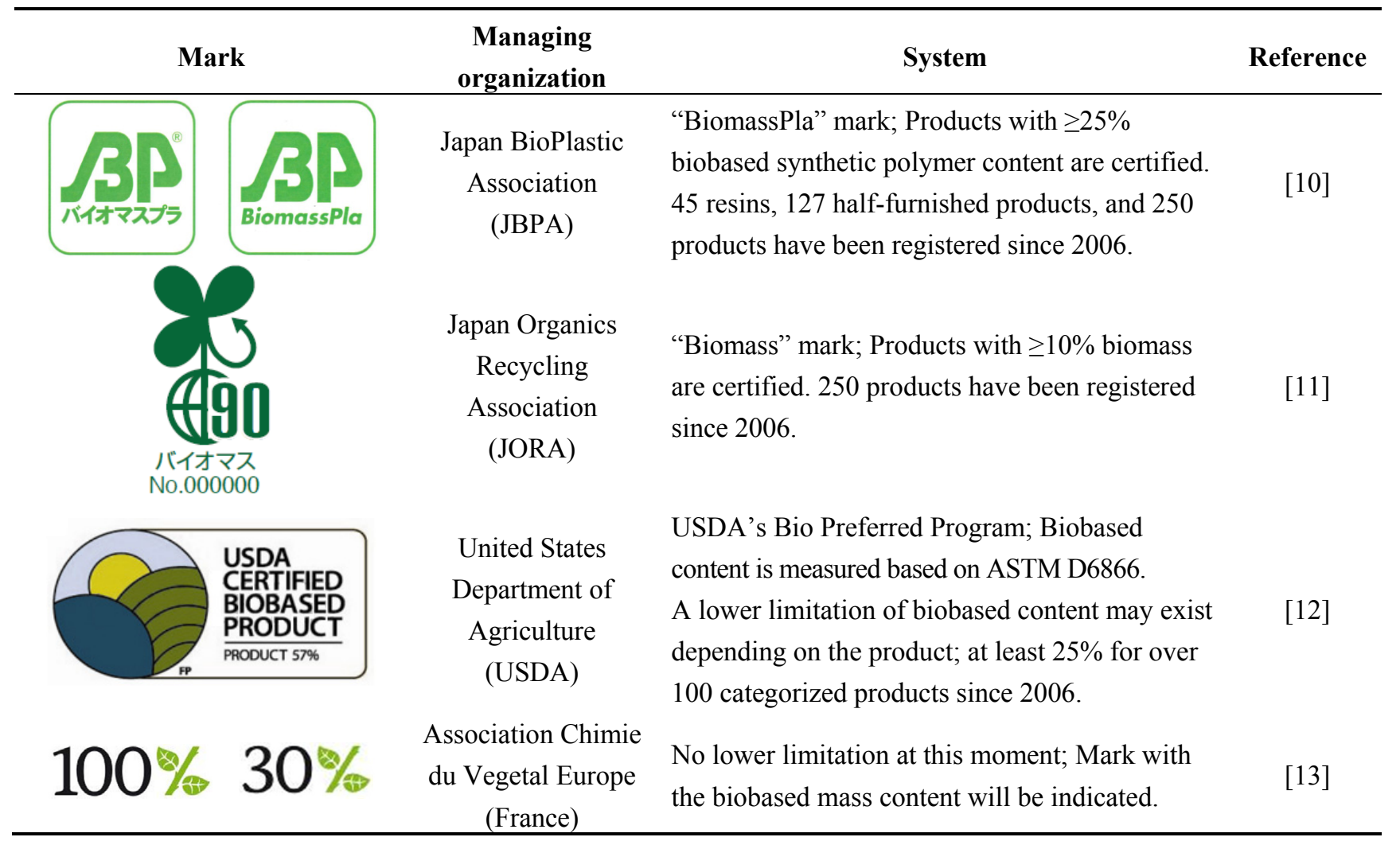


The difference between biobased carbon and fossil-based carbon in plastic or rubber products is determined by measuring the difference in the ratio of carbon isotopes $\left({ }^{12} \mathrm{C},{ }^{13} \mathrm{C}\right.$, and $\left.{ }^{14} \mathrm{C}\right)$ present in these products. Biobased carbon includes a very small amount of ${ }^{14} \mathrm{C}$, produced from ${ }^{14} \mathrm{~N}$ irradiated by cosmic radiation in the upper region of the atmosphere (Figure 2). Fossil-based carbons included ${ }^{14} \mathrm{C}$ initially, but all ${ }^{14} \mathrm{C}$, which is an unstable radiocarbon with a half-life of 5730 years, decayed during the long period of time spent underground by such carbons. The ratio of ${ }^{14} \mathrm{C}$ to ${ }^{12} \mathrm{C}$ in biobased carbon is $1 \times 10^{-12}$. The percent of modern carbon $(p \mathrm{MC})$ of biobased carbon from biomass harvested in 2010 is $104 \%$, which varied by $\pm 2 \%$ depending on the place and its situation. In addition, the value of $p \mathrm{MC}$ is decreasing gradually at approximately $0.5 \%$ /year and will gradually reach $100 \%$. The $p \mathrm{MC}$ value of fossil-based carbon is $0 \%$. The biobased carbon content for plastic products can be calculated by dividing the $p \mathrm{MC}$ value of the sample material by 1.04 , on the basis of CEN/TS 16137, or by multiplying the $p \mathrm{MC}$ value by 0.95 , on the basis of ASTM D6866-12 [14-17].

Figure 2. Mechanisms of ${ }^{14} \mathrm{C}$ insertion into biobased products.

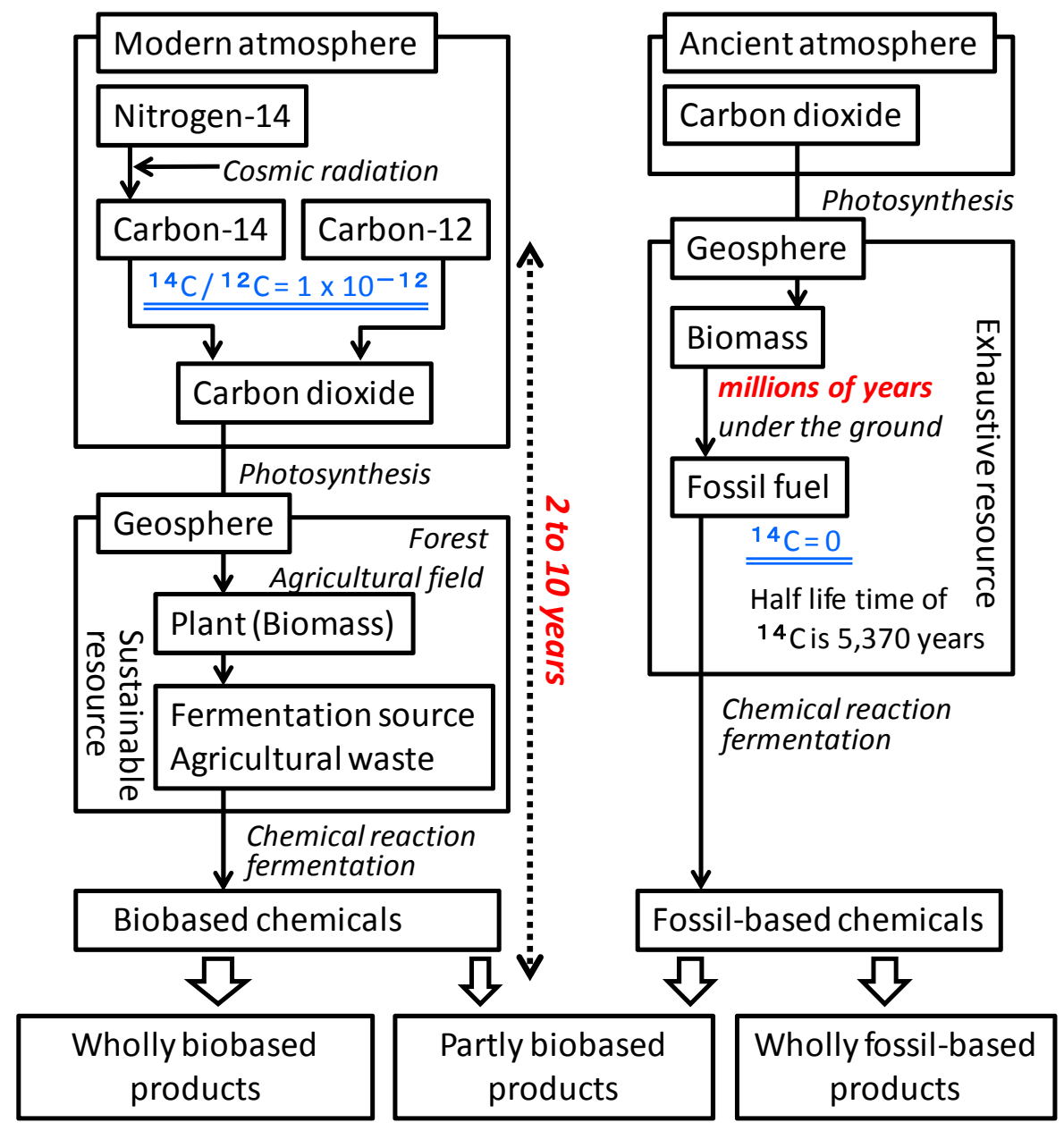

Some problems are associated with using the ISO 16620 series for rubber products. Rubber products include many types of ingredients such as silica and steel. One of the main components in rubber products is carbon black (CB), which improves the rubber's performance. For plastic products, the inorganic carbon components are assumed to be mainly calcium carbonate. Calcium carbonate in plastic products is treated by acid degradation, e.g., with hydrochloric or phosphoric acid, for 
evaluating the biobased content on the basis of ISO 16620 for plastics. However, this method is not applicable for $\mathrm{CB}$ in rubber products, because $\mathrm{CB}$ is stable under acidic conditions and cannot be transformed to $\mathrm{CO}_{2}$ by acid degradation. The biobased mass content and biobased carbon content for rubber products can be calculated from the composition of the feed constituents similar to that in plastic products. In addition, some composition analysis methods have been defined in the ISO standards (Table 4). It is possible to separate the defined constituents using these ISO standards. The biobased content of these separated constituent may be calculated using the biobased carbon content from the $p \mathrm{MC}$ value, which can be measured using the accelerator mass spectrometry (AMS) and a liquid scintillation counter (LSC); the carbon content by elemental analyses confirms the calculated values for the composition of rubber products.

Table 4. ISO standards related to composition analysis by separation of vulcanized rubber products published in ISO technical committee (TC) 45 "Rubber and rubber products".

\begin{tabular}{|c|c|c|}
\hline Method & $\begin{array}{c}\text { ISO } \\
\text { number }\end{array}$ & Title of standard \\
\hline Content of extract & ISO 1407 & Rubber-Determination of solvent extract \\
\hline $\begin{array}{l}\text { Separation of polymer } \\
\text { from vulcanized } \\
\text { rubber }\end{array}$ & ISO 4650 & Rubber-Identification-Infrared spectrometric method \\
\hline $\begin{array}{l}\text { Content of polymer, } \\
\text { carbon black, and } \\
\text { inorganics }\end{array}$ & ISO 9924-3 & $\begin{array}{l}\text { Rubber and rubber products-Determination of the composition of vulcanizates and } \\
\text { uncured compounds by thermogravimetry-Part 3: Hydrocarbon rubbers, } \\
\text { halogenated rubbers, and polysiloxane rubbers after extraction }\end{array}$ \\
\hline $\begin{array}{l}\text { Blend ratio of } \\
\text { polymer }\end{array}$ & ISO $7270-2$ & $\begin{array}{l}\text { Rubber-Analysis by pyrolytic gas-chromatographic methods-Part 2: } \\
\text { Determination of styrene/butadiene/isoprene ratio }\end{array}$ \\
\hline
\end{tabular}

The Japan Rubber Manufacturers Association (JRMA) plans to make the new ISOs applicable for determining the amount of biobased contents in rubber products. JRMA is responsible for maintaining the quality of Japanese rubber products worldwide [18]. In addition, JRMA is discussing ISO with the role of the sub committee (SC)'s chairman and secretariat of ISO/TC 45 (Rubber and rubber products)/SC 2 (Testing and analysis) and Japanese Industrial Standards (JIS) related to rubber products. To develop a new ISO standard for determining the biobased contents, a working team was organized by JRMA for a detailed discussion. The biobased contents for some types of rubber products as described in this paper were measured, and the methods of determination were developed by this working team. JRMA proposed these new ISO standards at the 61st annual meeting of TC 45, held in Bali (Indonesia), October 2013. The determination methods for biobased contents described in this paper will be discussed at the ISO TC 45 for new ISO documentation that will be used worldwide to promote and certify rubber products with higher biobased contents.

In this paper, a natural rubber model compound as a simulated tire rubber product was produced. The biobased contents of this model compound were calculated from the feed composition of the constituents and were determined by the $p \mathrm{MC}$ value calculated from the ${ }^{14} \mathrm{C}$ concentration using AMS and the carbon content from the elemental analyses of the separated constituents of this model compound. The calculated biobased contents were compared with those obtained from the feed 
composition. The international standardizations of these calculations and measuring methods at technical committee (TC) 45 "Rubber and rubber products" were discussed.

\section{Experimental Section}

\subsection{Preparation of Model Compound}

The natural rubber model compound for evaluating the biobased content of rubber products was prepared by the process summarized in Figure 3; its contents are shown in Table 5. Banbury mixing conditions were chosen as a Lamb pressure of $0.5 \mathrm{MPa}$ and rotating speed of $70 \mathrm{rpm}$. The mixing time and temperature in the first step without chemicals for the vulcanization were 3 min $45 \mathrm{~s}$ and $<170{ }^{\circ} \mathrm{C}$, respectively. The mixing time and temperature in the second step with chemicals for the vulcanization were $1 \mathrm{~min}$ and $<120^{\circ} \mathrm{C}$, respectively. The mixed compound was vulcanized at $145^{\circ} \mathrm{C}$ for 35 min.

\subsection{Solvent Extraction}

The separation methods of the rubber model compound were summarized at Figure 4. The vulcanized model compound was extracted in accordance with ISO 4650. That is, the model compound was cut into less than $2 \mathrm{~mm}$ by $2 \mathrm{~mm}$ fragments; then, $1 \mathrm{~g}$ of the fragments was extracted for $16 \mathrm{~h}$ with $180 \mathrm{~mL}$ of acetone using a Soxhlet extractor under $\mathrm{N}_{2}$.

Figure 3. Production of natural rubber model compound.

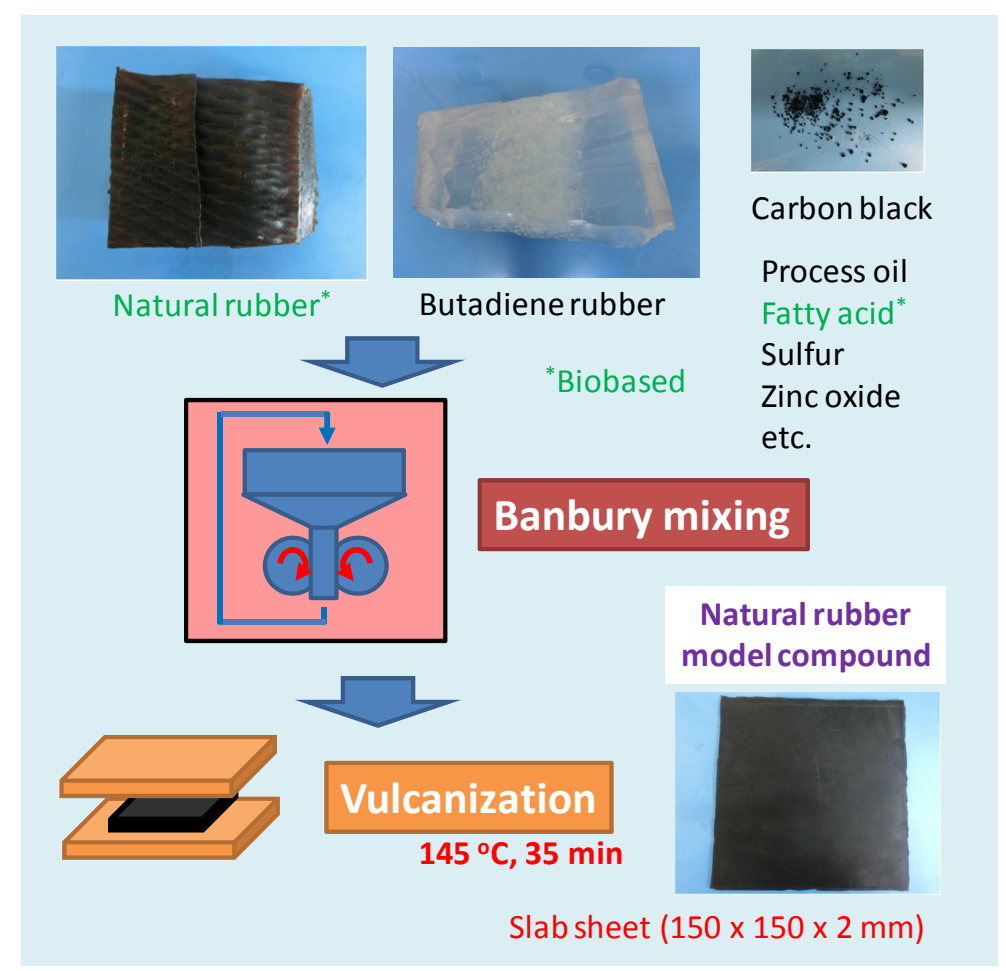


Table 5. Recipe of natural rubber model compound.

\begin{tabular}{|c|c|c|c|c|c|}
\hline Constituent & Phr ${ }^{1, *}$ & Mass\%, \% & $\begin{array}{c}\text { Biobased mass } \\
\text { content, } \%\end{array}$ & Carbon content, $\%$ & $\begin{array}{c}\text { Biobased carbon } \\
\text { content, } \%\end{array}$ \\
\hline Natural rubber & 60 & 37.4 & 100 & 38.1 & 100 \\
\hline Butadiene rubber & 40 & 24.9 & 0 & 25.5 & 0 \\
\hline Carbon black (CB) & 35 & 21.8 & 0 & 25.2 & 0 \\
\hline Process oil & 15.5 & 9.6 & 0 & 9.5 & 0 \\
\hline Zinc oxide $(\mathrm{ZnO})$ & 5.0 & 3.1 & 0 & 0 & 0 \\
\hline Fatty acid $2, *$ & 2.0 & 1.3 & 100 & 1.1 & 100 \\
\hline TBBS $^{3, *}$ & 0.7 & 0.5 & 0 & 0.3 & 0 \\
\hline $6 \mathrm{PPD}^{4, *}$ & 0.5 & 0.3 & 0 & 0.3 & 0 \\
\hline Sulfur & 1.8 & 1.1 & 0 & 0 & 0 \\
\hline $\begin{array}{l}\text { Total (model } \\
\text { compound) }\end{array}$ & 160.5 & 100.0 & $38.7^{5, *}$ & 100.0 & $39.2^{6, *}$ \\
\hline
\end{tabular}

Notes: ${ }^{1, *}$ phr is parts by weight per 100 parts by weight of rubber, ${ }^{2, *}$ Biobased stearic acid and palmitic acid (60/40 mass\%) were added; ${ }^{3, *}$ TBBS is $N$-tert-butyl-2-benzothiazole sulfonamide; ${ }^{4, *}$ 6PPD is $N-(1,3-$ dimethylbutyl)- $N^{\prime}$-phenyl-p-phenylenediamine; ${ }^{5, *}$ Biobased mass content of this model composite is sum of 37.4 and 1.3, which are mass\% values of biobased constituents based on ISO 16620-4; ${ }^{6, *}$ Biobased carbon content of this model composite is sum of 38.1 and 1.1, which are carbon contents of biobased constituents based on ISO 16620-2.

Figure 4. Separation methods based on ISOs for natural rubber model compound. carbon black (CB); zinc oxide ( $\mathrm{ZnO})$; elemental analysis (EA); accelerator mass spectroscopy (AMS).

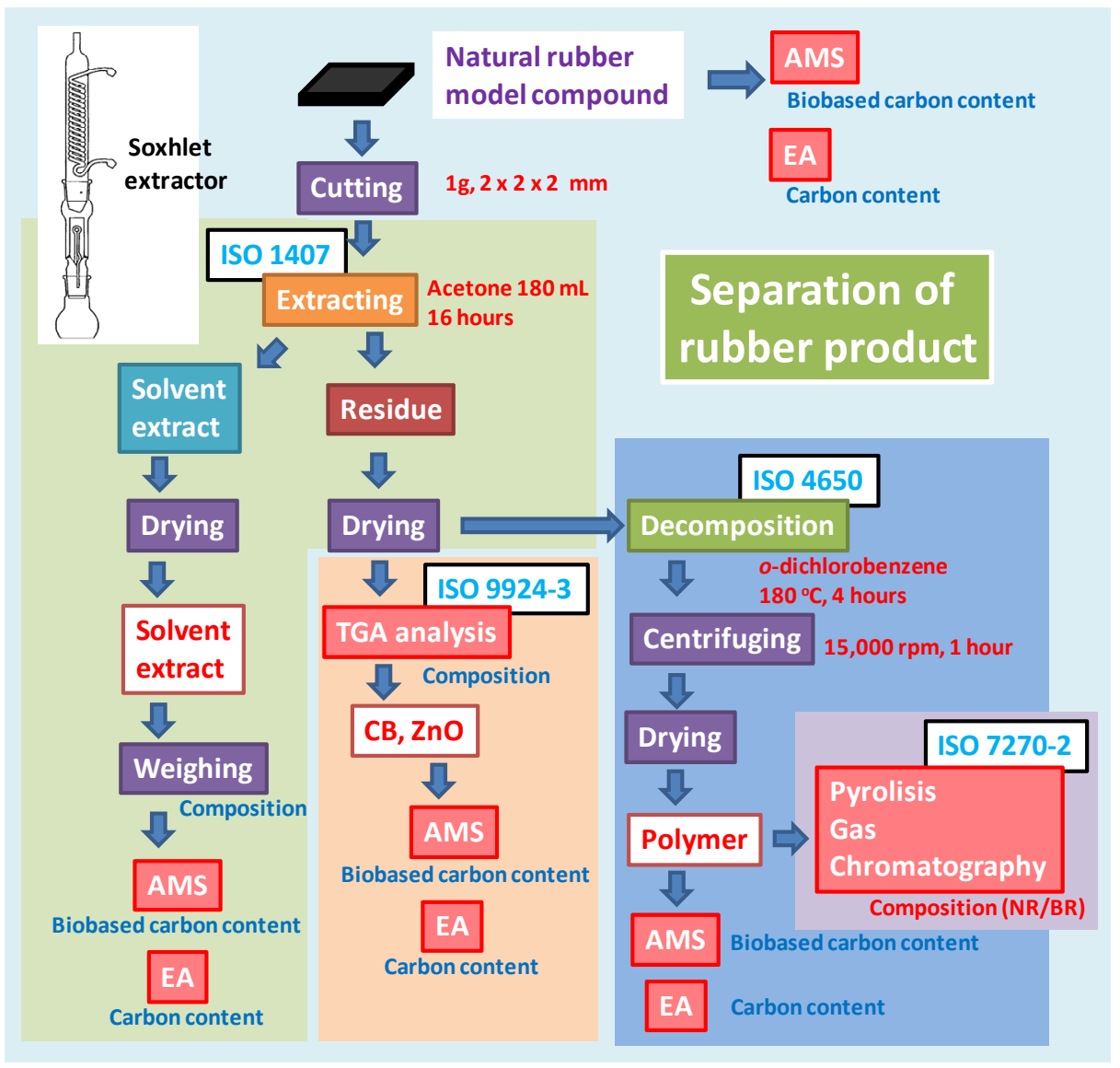




\subsection{Separation of Rubber from Compound}

First, $100 \mathrm{mg}$ of the extracted fragments was decomposed with $o$-dichlorobenzene at its boiling temperature $\left(180{ }^{\circ} \mathrm{C}\right)$ for $4 \mathrm{~h}$ under $\mathrm{N}_{2}$ in accordance with Section 7.3.1. of ISO 4650 [19]. CB and inorganics were removed from the decomposition liquid using a centrifugal separator at 15,000 rpm for $60 \mathrm{~min}$.

\subsection{Determination of Blend Ratio of Separated Rubber}

The blend ratio of natural rubber (NR) and butadiene rubber (BR) of the separated rubber from the vulcanized model compound was determined in accordance with ISO 7270-2. That is, the rubber was decomposed at $600{ }^{\circ} \mathrm{C}$ using a micro-furnace pyrolyzer (Frontier Lab, Koriyama, Japan), and the decomposed components were analyzed by gas chromatography (Agilent Technologies, Inc., Santa Clara, CA, USA) directly connected to the pyrolyzer; the blend ratio was calculated using a standard curve prepared beforehand.

\subsection{Separation of CB and Inorganics from Model Compound}

$\mathrm{CB}$ and inorganics were separated from the vulcanized model compound by thermogravimetry (Hitachi High-Tech Science Corporation, Tokyo, Japan) under the conditions shown in Table 6 and Figure 5.

\subsection{Determination of Composition of Vulcanized Rubber after Extraction}

The composition ratio of the rubber, $\mathrm{CB}$, and inorganics of the extracted model compound was determined in accordance with ISO 9924-3. The results of the determination of the composition ratio are shown in Figure 5.

Table 6. Operating conditions for separation of CB and/or inorganics by thermogravimetry.

\begin{tabular}{ccc}
\hline Step & Units & $\begin{array}{c}\text { Separation of carbon } \\
\text { black and inorganics }\end{array}$ \\
\hline Initial temperature & ${ }^{\circ} \mathrm{C}$ & $35 \pm 10$ \\
Heating under nitrogen & ${ }^{\circ} \mathrm{C} / \mathrm{min}$ & 20 \\
Target temperature under nitrogen & $\mathrm{min}$ & 600 \\
Cooling under nitrogen & ${ }^{\circ} \mathrm{C}$ & 400 \\
Holding temperature at atmosphere change under air in the case of heating & $\mathrm{min}$ & 2 \\
[Cooling] Cooling under nitrogen & ${ }^{\circ} \mathrm{C} / \mathrm{min}$ & 50 \\
Final temperature under nitrogen & ${ }^{\circ} \mathrm{C}$ & 35 \\
[Heating] Heating under air & ${ }^{\circ} \mathrm{C} / \mathrm{min}$ & 20 \\
Final temperature under air & ${ }^{\circ} \mathrm{C}$ & 800 \\
\hline
\end{tabular}


Figure 5. Composition ratio of rubber, $\mathrm{CB}$, and inorganics of extracted model compound as determined by thermogravimetric analysis.

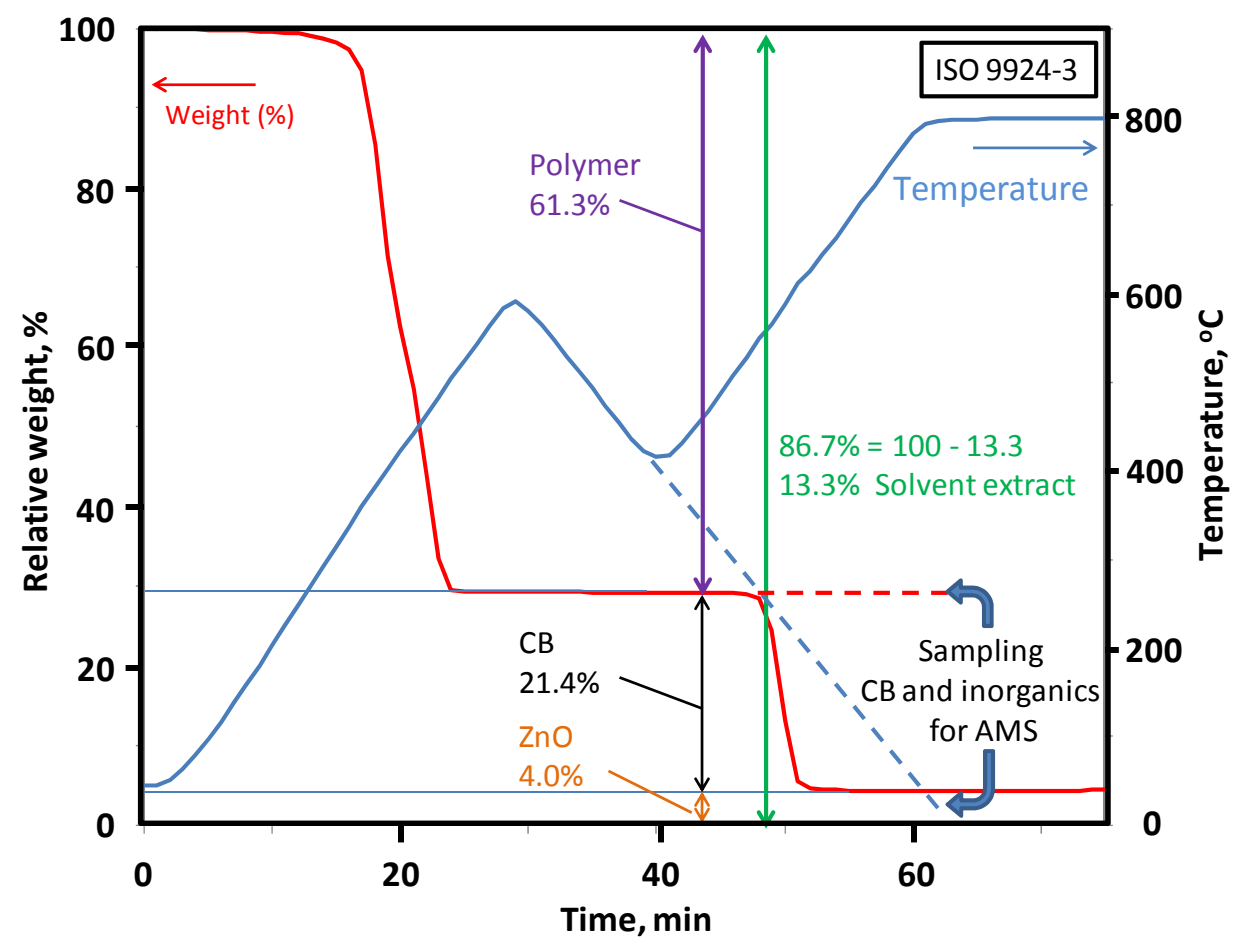

\subsection{Sample Preparation for Measurement of Biobased Carbon Content}

Pretreatment of the samples for AMS measurements was performed at the Institute of Accelerator Analysis, Ltd. (IAA; Fukushima, Japan). All carbon atoms in the samples were transformed to graphite carbons by serial oxidation and reduction reactions using an elemental analyzer and a vacuum manifold system (Figure 6). The sample (3 mg of carbons) in a tin cup was oxidized by an elemental analysis apparatus EA1110 (CE Instruments Ltd., Hindley Green, Wigan, UK) under helium gas with oxygen gas at $980{ }^{\circ} \mathrm{C}$. The oxidized mixed gas was transferred to a gas manifold system. Subsequently, $\mathrm{CO}_{2}, \mathrm{CO}$, and $\mathrm{H}_{2} \mathrm{O}$ were cold-trapped in another tube using dry ice/ethanol $\left(-76{ }^{\circ} \mathrm{C}\right)$ connected to a closed vacuum line system. The cold-trap step was repeated twice. Pure $\mathrm{CO}_{2}$ was cold-trapped in a quartz glass tube with pure ferrous powder in liquid $\mathrm{N}_{2}\left(-196^{\circ} \mathrm{C}\right)$; the other reactants such as $\mathrm{CO}$ and $\mathrm{H}_{2} \mathrm{O}$ were cold-trapped in another tube under dry ice/ethanol. $\mathrm{CO}_{2}$ with ferrous powder and hydrogen gas in a sealed quartz tube was reduced to graphite by heating at $650{ }^{\circ} \mathrm{C}$ for $10 \mathrm{~h}$. After these processes, pure graphite and oxidized iron $(1 \mathrm{mg})$ were transferred to a sample holder (small rod shape; 1-mm hole). 
Figure 6. Sample pretreatment method for AMS.

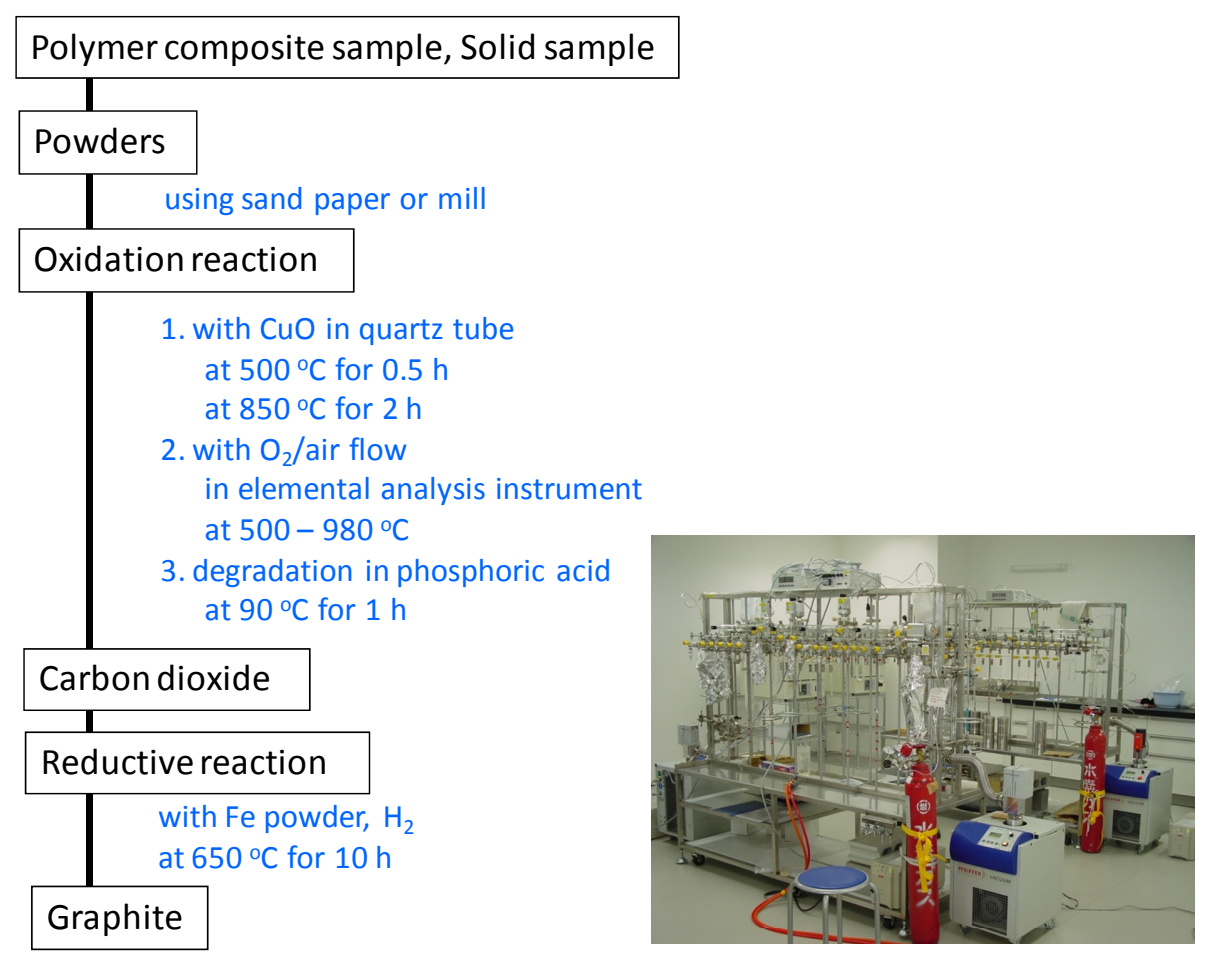

\subsection{Measurement of Biobased Carbon Content}

The measurement of the ratios of the three carbon isotopes $\left({ }^{14} \mathrm{C},{ }^{13} \mathrm{C}\right.$, and $\left.{ }^{12} \mathrm{C}\right)$ using AMS was performed at the IAA. Our measurements were obtained using a 3-MV tandem accelerator system (National Electrostatics Co., Middleton, WI, USA) at the IAA (Figure 7). The graphite from the sample was ionized using a cesium-cation beam. The reduced carbon atoms were accelerated using a 3-MV tandem accelerator (National Electrostatics Co., Middleton, WI, USA, Pelletron 9SDH-2). The amounts of ${ }^{12} \mathrm{C}$ and ${ }^{13} \mathrm{C}$ were detected as currents using multi-Faraday cups. The ${ }^{14} \mathrm{C}$ atoms were detected using a $\Delta E-E$ detector. The value of $p \mathrm{MC}$ was calculated from the ${ }^{14} \mathrm{C} /{ }^{12} \mathrm{C}$ concentration ratio in the sample. The biobased carbon content was determined from the ${ }^{14} \mathrm{C}$ concentration measured using AMS as per the ISO/DIS 16620-2 standard method. The reference materials were measured for the obtained graphite using AMS. The biobased carbon contents were calculated as follows:

$$
\begin{gathered}
{ }^{14} \mathrm{As}={ }^{14} \mathrm{C} /{ }^{12} \mathrm{C} \text { in sample } \\
{ }^{14} \mathrm{Ar}={ }^{14} \mathrm{C} /{ }^{12} \mathrm{C} \text { in reference material } \\
\Delta{ }^{14} \mathrm{C}=\left[\left({ }^{14} \mathrm{As}-{ }^{14} \mathrm{Ar}\right) /{ }^{14} \mathrm{Ar}\right] \times 1000(\%) \\
p \mathrm{MC}=\Delta{ }^{14} \mathrm{C} / 10+100(\%)
\end{gathered}
$$

biobased carbon content $=p \mathrm{MC} / 105 \times 100(\%)$ 
Figure 7. Outline of AMS apparatus.
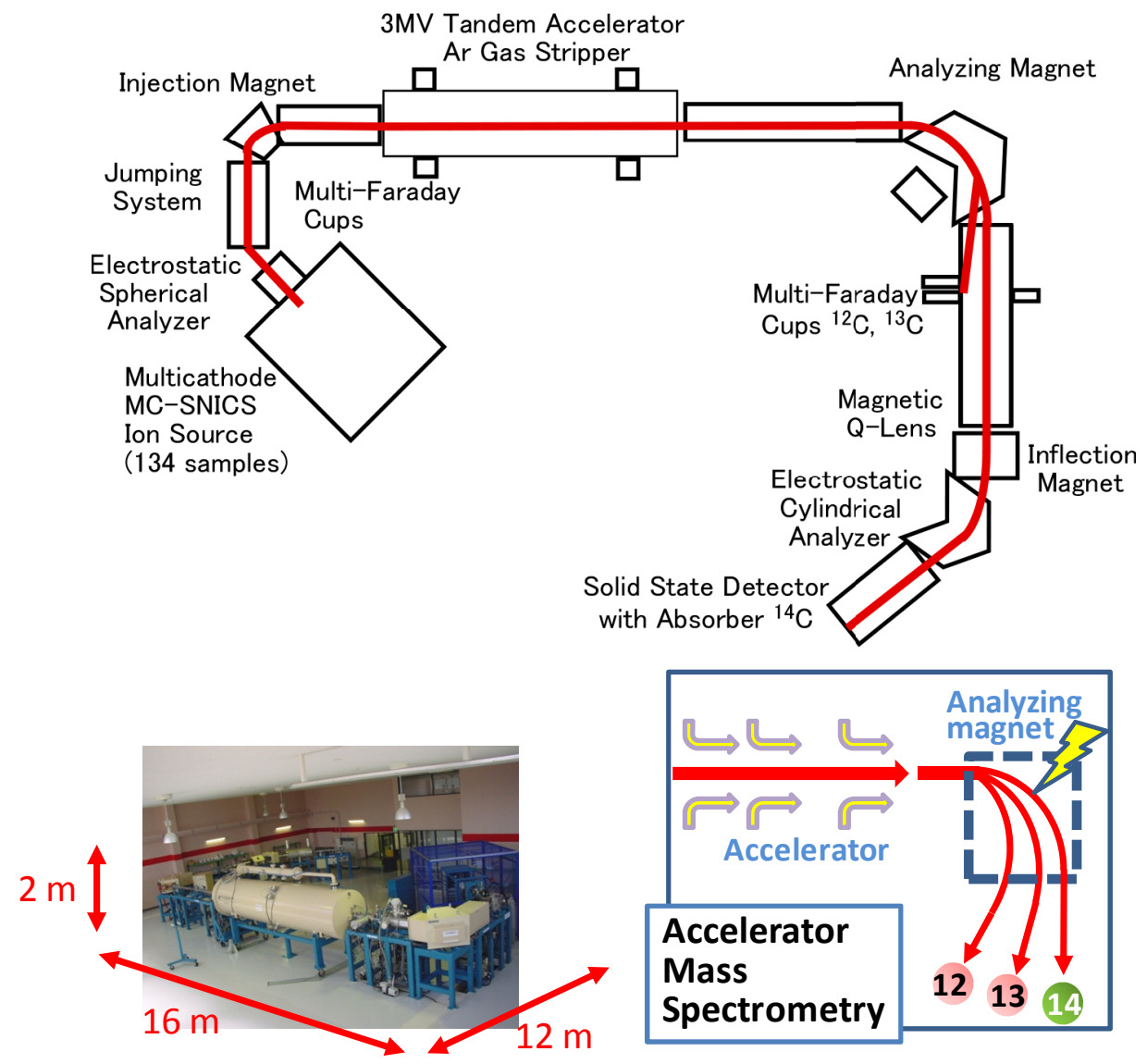

$\Delta{ }^{14} \mathrm{C}$ is the isotope differential ratio of ${ }^{14} \mathrm{C}$ between the sample and the reference material, and $p \mathrm{MC}$ is the percent of modern carbon. Modern-carbon-based oxalic acid radiocarbon (standard reference material (SRM) 4990c, National Institute of Standards, Gaithersburg, MD, USA) was used as the reference material. The $p \mathrm{MC}$ value for petroleum-based carbon is $0 \%$, and that for biomass produced by $\mathrm{CO}_{2}$ fixation in the atmosphere by photosynthesis was $105 \%$ in 2010 . The $p \mathrm{MC}$ value can be slightly higher than $100 \%$ because of the continuing, but diminishing, effects of atmospheric nuclear-testing programs carried out during the $1950 \mathrm{~s}$. During this period, large amounts of ${ }^{14} \mathrm{C}$ were emitted into the atmosphere. Because ${ }^{14} \mathrm{C}$ in all the samples is referenced to a "prebomb" standard, all $p \mathrm{MC}$ values must be divided by 105 to correct for the bomb carbon and to obtain the true biobased carbon content of the sample, as indicated in Equation (5), as per ISO/DIS 16620-2. For carbon-dating measurements, ${ }^{14} \mathrm{C}$ concentrations (As) were calculated with the correction of $\delta^{13} \mathrm{C}$ of the measured sample, as indicated in Equation (6). However, the difference range of $\delta^{13} \mathrm{C}$ in fossil-based carbon is larger than that in biobased carbons. Therefore, the correction by $\delta^{13} \mathrm{C}$ for the ${ }^{14} \mathrm{C}$ concentration was not performed to determine the ${ }^{14} \mathrm{C}$ concentration in this paper.

$$
{ }^{14} \mathrm{As}={ }^{14} \mathrm{As}\left(0.975 /\left(1+\delta^{13} \mathrm{C} / 1000\right)\right)^{2}
$$




\subsection{Elemental Analysis}

To determine the carbon content of the separated constituents of the natural rubber model compound, elemental analyses of carbon, hydrogen, and nitrogen were performed using an elemental analysis apparatus EA1110 (CE Instruments Ltd., Wigan, UK).

\section{Results and Discussion}

\subsection{Calculation of Biobased Mass Content and Biobased Carbon Content of Natural Rubber Model Compound}

It is very important to accurately evaluate the biobased content of the rubber product using the international standards for promoting rubber products with higher percentages of biobased constituents. With regard to plastic products, the biobased carbon content and biobased mass content were defined by the ISO 16620 series, as explained in the Introduction. Similarly, rubber-producing companies can calculate these biobased contents from its feed compositions, as shown in Table 5. The biobased mass content is defined on the basis of the mass of biobased constituents, as explained in Table $2\left(m_{\mathrm{B}}\right)$. The biobased constituents of the natural rubber model compound are natural rubber $(37.4 \%)$ and fatty acid (1.3\%). Therefore, the biobased mass content of the model compound is $38.7 \%(=37.4 \%+1.3 \%)$.

The biobased carbon content is defined on the basis of the mass of the carbon in the biobased constituents (Table 2) $\left(x_{\mathrm{B}}^{\mathrm{TC}}\right)$. In rubber compounds, $\mathrm{CB}$ is an important constituent as an inorganic filler. Some companies are making an effort to change from fossil-based $\mathrm{CB}$ to biobased $\mathrm{CB}$ carbonized from biomass resources. The amount of $\mathrm{CB}$ is ignored when calculating the biobased carbon content to total organic carbon $\left(x_{\mathrm{B}}^{\mathrm{TOC}}\right)$; it is taken into consideration for calculating the biobased carbon content to total carbon $\left(x_{\mathrm{B}}^{\mathrm{TC}}\right)$. In this paper, the biobased carbon contents were calculated with respect to the total carbon in the product $\left(x_{\mathrm{B}}^{\mathrm{TC}}\right)$ and not the total organic carbon $\left(x_{\mathrm{B}}^{\mathrm{TOC}}\right)$ (Table 2). For calculating the biobased carbon contents of the model compound, the carbon content of each constituent should be calculated. The total carbon content of natural rubber and fatty acid, which are biobased, are $38.1 \%$ and $1.1 \%$, respectively. Thus, the biobased carbon content is $39.2 \%(=38.1 \%+1.1 \%)$.

In this way, the biobased mass content can be easily calculated from the mass of the constituents, and the biobased carbon content can be calculated from the mass of carbon (carbon content) of the constituents of the rubber compound. Companies producing rubber products can calculate these biobased contents from the feed composition of their products and the carbon content according to the chemical structure of the product constituents.

\subsection{Separation of Natural Rubber Model Compound for Composition Analysis}

For quality control and performance evaluation of rubber products, some composition analysis methods have been developed by ISO, as explained in the Introduction (Table 4). Table 7 shows the composition, results of the elemental analyses, and theoretical and experimental carbon contents. The amount of the solvent extract was determined by acetone extraction based on ISO 1407. The solvent extract may include process oil, fatty acid $N$-tert-butyl-2-benzothiazole sulfenamide (TBBS), and $N$-(1,3-dimethylbutyl)- $N$ '-phenyl-p-phenylenediamine (6PPD). In addition, a small part of the 
rubber constituent (polymer) may be extracted. Therefore, the measured amount of this part should be higher than that in the feed composition. The other three parts-polymer with sulfur, $\mathrm{CB}$, and zinc oxide ( $\mathrm{ZnO}$ ) — were determined by thermogravimetric analysis (TGA) based on ISO 9924-3 (Figure 5).

Table 7. Composition, results of elemental analysis, and carbon contents in separated constituents of natural rubber model composite.

\begin{tabular}{|c|c|c|c|c|c|c|c|c|}
\hline \multirow{2}{*}{$\begin{array}{l}\text { Separated } \\
\text { constituent }\end{array}$} & \multirow{2}{*}{$\begin{array}{c}\text { Calculated } \\
\text { composition, } \\
\%\end{array}$} & \multirow{2}{*}{$\begin{array}{c}\text { Measured } \\
\text { composition, } \\
\%\end{array}$} & \multicolumn{4}{|c|}{ Elemental analysis (EA), \% } & \multirow{2}{*}{$\begin{array}{c}\text { Theoretical } \\
\text { carbon } \\
\text { content in } \\
\text { each } \\
\text { constituent, \% }\end{array}$} & \multirow{2}{*}{$\begin{array}{c}\text { Measured } \\
\text { carbon } \\
\text { content }^{1, *}, \\
\%\end{array}$} \\
\hline & & & $\mathbf{C}$ & $\mathbf{H}$ & $\mathbf{N}$ & Others & & \\
\hline $\begin{array}{l}\text { Solvent } \\
\text { extract }\end{array}$ & $11.7^{2, *}$ & 13.3 & 84.43 & 12.83 & 0.27 & 2.47 & 83.4 & 13.13 \\
\hline Polymer & $63.4^{3, *}$ & 61.3 & 86.27 & 11.26 & 0.06 & 2.41 & 88.5 & 61.84 \\
\hline $\mathrm{CB}$ & 21.8 & 21.4 & \multirow{2}{*}{80.75} & \multirow{2}{*}{0.44} & \multirow{2}{*}{0.26} & \multirow{2}{*}{18.55} & \multirow{2}{*}{84.3} & 25.03 \\
\hline $\mathrm{ZnO}$ & 3.1 & 4.0 & & & & & & 0 \\
\hline Compound & 100 & 100 & 83.61 & 8.48 & 0.35 & 7.54 & 86.7 & 100 \\
\hline
\end{tabular}

Notes: ${ }^{1, *}$ Measured carbon content was calculated from the product of measured composition and carbon content by EA. Carbon content of CB was assumed to be $100 \%$. Measured carbon contents were corrected so that their sum was $100 \% .{ }^{2, *}$ Solvent extract includes process oil, fatty acid, TBBS, and 6PPD, as shown in Table $5 ;{ }^{3, *}$ Polymer includes natural rubber, butadiene rubber, and sulfur.

For elemental analysis and AMS, the polymer part of the compound was separated by decomposing it in boiling $O$-dichlorobenzene $\left(180{ }^{\circ} \mathrm{C}\right)$ for $4 \mathrm{~h}$; then, the solid parts containing the insoluble rubber were eliminated by centrifugation. Approximately $85 \%$ of the polymer (rubber part) was separated from the model compound. The $\mathrm{CB}$ and $\mathrm{ZnO}$ mixture was separated by thermally degrading the residue by acetone extraction at $600{ }^{\circ} \mathrm{C}$ under nitrogen gas in a TGA apparatus (Figure 5), before oxidizing the $\mathrm{CB}$. The model compound, separated solvent extract, polymer, and $\mathrm{CB}$ and $\mathrm{ZnO}$ mixture from the model compound were characterized by elemental analysis to determine the carbon contents of each constituent. The total carbon contents of each constituent were determined (Table 7).

\subsection{Determination of Biobased Carbon Content}

To confirm the biobased or fossil-based sources of the natural rubber model compound, the biobased carbon contents were measured as shown in Table 8. The butadiene rubber and CB were completely fossil-based and did not have any ${ }^{14} \mathrm{C}$. The fatty acid was entirely biobased. In contrast, the natural rubber used in this paper was almost biobased, but a very small amount (3\% of the carbon mass in the natural rubber) of fossil-based chemicals (unknown) was used in rubber production. 
Table 8. Percent of modern carbon $(p \mathrm{MC})$ determined from ${ }^{14} \mathrm{C}$ concentration measured by AMS and biobased carbon content calculated from $p \mathrm{MC}$ for feed constituents.

\begin{tabular}{ccc}
\hline Resource & $\boldsymbol{p} \mathbf{M C}^{\mathbf{1}, \boldsymbol{\%}} \mathbf{\%}$ & Biobased carbon content $^{\mathbf{2}, \boldsymbol{\%}} \mathbf{\%}$ \\
\hline Natural rubber & 101.81 & 96.96 \\
Butadiene rubber & $<0.13$ & $<0.12$ \\
CB & $<0.13$ & $<0.12$ \\
Fatty acid & 103.67 & 98.73 \\
\hline
\end{tabular}

Notes: ${ }^{1, *} p \mathrm{MC}$ is percent of modern carbon calculated using ${ }^{14} \mathrm{C}$ concentration as measured by AMS;

${ }^{2, *}$ Biobased carbon content was calculated using Equation (5).

The biobased carbon contents of the model compound and separated solvent extract, polymer, and $\mathrm{CB}$ and $\mathrm{ZnO}$ mixture were determined by AMS using Equations (1-5) (Table 9). Using these measurements, the biobased carbon content of the model compound was determined to be $37.6 \%$ (37.56\%); the calculation is shown in Equation (7).

Biobased carbon content of this compound $=39.44 \times 100 / 105=37.56 \%$

Table 9. $p \mathrm{MC}$ determined from ${ }^{14} \mathrm{C}$ concentration measured by AMS and biobased carbon content calculated from $p \mathrm{MC}$ for separated constituents and model compound.

\begin{tabular}{|c|c|c|c|}
\hline Separated constituent & $\begin{array}{l}\text { Theoretical biobased } \\
\text { carbon content }{ }^{1, *}, \%\end{array}$ & $p \mathrm{MC}^{2, *}, \%$ & $\begin{array}{c}\text { Biobased carbon } \\
\text { content }\end{array}$ \\
\hline Solvent extract & 9.8 & 11.11 & 10.58 \\
\hline Polymer & 59.9 & 62.27 & 59.30 \\
\hline $\mathrm{CB}$ and $\mathrm{ZnO}$ & 0 & 0.90 & 0.86 \\
\hline Model compound & 39.2 & 39.44 & 37.56 \\
\hline
\end{tabular}

The calculated values of the biobased carbon content agreed well with the theoretical values, except those for CB. For the polymer constituent, the calculated biobased carbon content $(59.3 \%)$ was the same as the theoretical biobased carbon content (59.9\%). This indicates that the natural and butadiene rubbers were extracted with the same ratio in the model compound, despite the recovery of the polymer being approximately $85 \%$. Any procedure to increase the yield of the recovered rubber for this process may contaminate the other solid parts. In the case of $\mathrm{CB}$, a very small amount of natural rubber may be adsorbed, or char from the natural rubber may be produced at the $\mathrm{CB}$ surface in the TGA apparatus. However, the difference between the biobased carbon contents for the added and separated CB was very small (under $1 \%$ ).

To confirm the accuracy of these calculations, the biobased carbon content was calculated from the $p \mathrm{MC}$ of the separated constituents (Table 10). The carbon mass of the biobased and fossil-based contents of each constituent can be calculated by multiplying the biobased carbon and total carbon contents (Table 10). The calculated biobased carbon content was $38.3 \%$, which is in good agreement with the theoretical value $(39.2 \%$ in Table 5$)$ and the calculated value from the $p \mathrm{MC}$ value of the compound (37.6\% in Equation (7)). These calculation procedures are not required for determining the 
biobased total carbon content of the rubber product, because the measurement of $p \mathrm{MC}$ for the rubber product was sufficient to determine the biobased carbon content (Equation (7)).

Table 10. Calculated biobased and fossil-based carbon masses for separated constituents.

\begin{tabular}{cccc}
\hline \multirow{2}{*}{ Separated constituent } & \multirow{2}{*}{ Carbon content $^{\mathbf{1}, *}, \boldsymbol{\%}$} & \multicolumn{2}{c}{ Carbon mass, $\%$} \\
\cline { 3 - 4 } & & Biobased $^{2, *}$ & Fossil-based \\
\hline Solvent extract & 13.13 & 1.39 & 11.74 \\
Polymer & 61.84 & 36.67 & 25.17 \\
CB & 25.03 & 0.21 & 24.82 \\
ZnO & 0 & 0 & 0 \\
Total (model compound) & 100 & 38.3 & 61.7 \\
\hline 1,* Measured carbon contents are indicated in Table $7 ;^{2, *}$ Biobased carbon mass can be calculated by \\
ying biobased carbon content with total carbon mass (content).
\end{tabular}

\subsection{Determination of Biobased Mass Content}

The biobased mass content of the model compound was calculated; the results are given in Table 11. The biobased and fossil-based composition cannot be obtained from the measured biobased carbon content of each constituent, because the carbon content of the feed chemicals in the separated constituents are not same. In addition, the constituents of the samples for these evaluation methods will be unknown. However, the carbon contents of the polymers (rubbers) are almost the same; for example, the carbon contents of natural rubber and butadiene rubber are $88.2 \%$ and $88.9 \%$, respectively. Thus, the carbon contents of the biobased and fossil-based materials in each constituent are assumed to be the same. In such a case, the biobased material mass in each constituent can be calculated by multiplying the biobased carbon content with the mass of its constituent. The biobased mass content of this compound was $37.9 \%$ (Table 11). This value was in good agreement with the calculated value $(38.7 \%)$ given in Table 5 .

Table 11. Calculated biobased and fossil-based masses for separated constituents.

\begin{tabular}{cccc}
\hline \multirow{2}{*}{ Separated constituent } & Composition, \% & \multicolumn{2}{c}{ Composition, \% } \\
\cline { 3 - 4 } & & Biobased ${ }^{\mathbf{1} * *}$ & Fossil-based \\
\hline Solvent extract & 13.3 & 1.41 & 11.89 \\
Polymer & 61.3 & 36.35 & 24.95 \\
CB & 21.4 & 0.18 & 21.22 \\
ZnO & 4.0 & 0 & 4.0 \\
Total (model compound) & 100 & 37.9 & 62.1 \\
\hline${ }^{1, *}$ Biobased material mass in each constituent was calculated by multiplying biobased carbon content \\
composition. It was assumed that carbon contents of biobased and fossil-based materials in each
\end{tabular}

\subsection{Determination of the Composition of Vulcanized Rubber after Extraction}

To confirm the blend ratio of the natural and butadiene rubbers based on ISO 7270-2, the monomer ratio of isoprene and butadiene for the separated polymer was measured using pyrolysis gas chromatography (Py-GC) (Table 12). The composition of the natural and butadiene rubbers measured 
using Py-GC was the same as that calculated from the feed composition. This result indicates that the selectivities for the extraction procedure for each rubber are the same, as explained by the results of the biobased carbon content listed in Table 8 .

Table 12. Blend ratio of separated rubber from vulcanized rubber based on ISO 7270-2.

\begin{tabular}{ccc}
\hline Rubber constituent & Natural rubber, mass\% & Butadiene rubber, mass\% \\
\hline Separated rubber & 61 & 39 \\
Recipe of vulcanized rubber & 60 & 40 \\
\hline
\end{tabular}

\section{Conclusions}

To evaluate the biobased contents of rubber products, a natural rubber model compound with synthetic rubber, process oil, fatty acid, $\mathrm{CB}, \mathrm{ZnO}$, and sulfur was produced. The biobased mass content of this compound could be easily calculated from the feed composition based on ISO 16620-4. The biobased carbon content of this model compound could be calculated from the carbon mass in each constituent, which could be calculated from the molecular structure and mass of the constituent as per ISO 16620-2. To confirm these biobased contents of this model compound by analytical methods, the compound was separated into its constituents (solvent extract, polymer, $\mathrm{CB}$, and $\mathrm{ZnO}$ ). The composition of the four constituents could be determined by acetone extraction based on ISO 1407 and TGA based on ISO 9924-3. The polymer fraction and $\mathrm{CB}$ and $\mathrm{ZnO}$ mixture could be separated by using $O$-dichlorobenzene (ISO 4650). The $\mathrm{CB}$ and $\mathrm{ZnO}$ mixture was separated by the thermal degradation of the polymer. From the $p \mathrm{MC}$ value measured by AMS for each separated constituent, it was possible to evaluate which constituent included biobased materials. In addition, the biobased contents of this model compound as determined by the method described in this paper agreed well with the values calculated from the feed composition. The accuracy was confirmed to meet the international standard's methods of determination by comparing the calculated values from the feed composition and the measured values from the analytical methods described in this paper. The biobased mass and biobased carbon contents for the rubber product used in this paper are summarized in Table 13. To promote these theoretical and analytical methods for calculating the biobased contents of rubber products worldwide, these methods, as shown in Figure 8, should be published in ISO after a detailed discussion at TC45 "Rubber and rubber product."

Table 13. Biobased contents based on proposed ISO for rubber products.

\begin{tabular}{cccc}
\hline $\begin{array}{c}\text { Biobased } \\
\text { content }\end{array}$ & Definition & $\begin{array}{c}\text { New } \\
\text { ISO }\end{array}$ & Summary \\
\hline $\begin{array}{c}\text { Biobased } \\
\text { mass } \\
\text { content }\end{array}$ & $\begin{array}{c}\text { Amounts of biobased } \\
\text { synthetic polymer, natural } \\
\text { polymer, and biobased } \\
\text { additives in the product }\end{array}$ & Part 2 & $\begin{array}{c}\text { Easy understanding; Calculable using only the feed } \\
\text { composition (phr); Complex evaluation from EA and AMS } \\
\text { for unknown samples; Useful for components without } \\
\text { carbon (silica or steel) }\end{array}$ \\
$\begin{array}{c}\text { Biobased } \\
\text { carbon } \\
\text { content }\end{array}$ & $\begin{array}{c}\text { Amount of carbon derived } \\
\text { from biomass present in } \\
\text { the product (total carbon) }\end{array}$ & Part 3 & $\begin{array}{c}\text { Base data for } \mathrm{CO}_{2} \text { emission during thermal recycling; } \\
\text { Complex calculation of the carbon content from the feed } \\
\text { composition; Easy evaluation using AMS for unknown } \\
\text { samples; No change by adding ingredients without carbon } \\
\text { (silica or steel) }\end{array}$ \\
\hline
\end{tabular}


Figure 8. Determination methods of biobased contents for ISO evaluation methods.

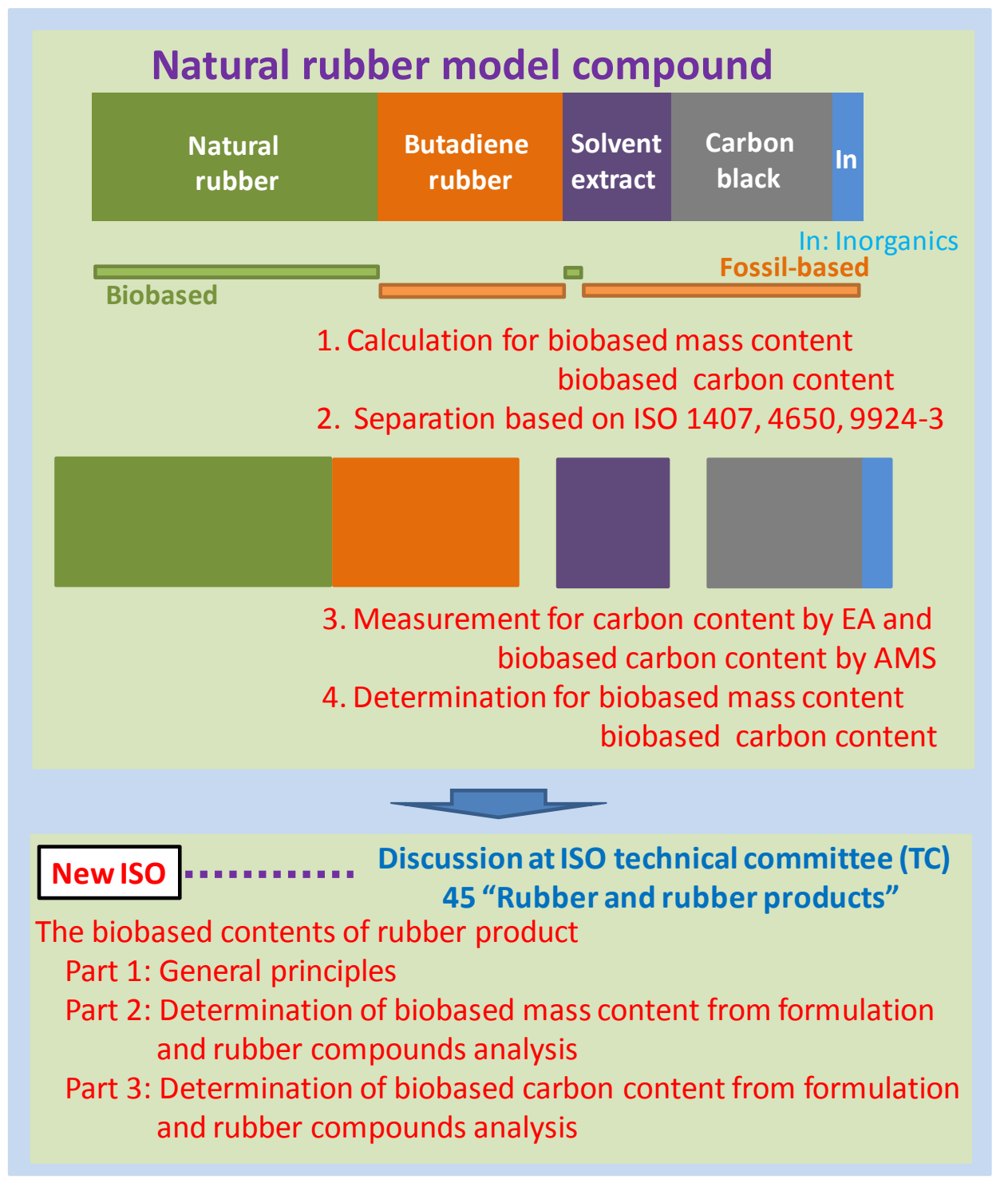

\section{Acknowledgment}

The authors are thankful for the financial support provided by the Japan Rubber Manufacturers Association (JRMA) and discussions with the biobased working team of JRMA. This separation concept was part of the results from the Research Project entitled "Development of Preparatory Basic Bioenergy Technologies: Accelerated Technology Development for Biofuel: R\&D of Method to Measure Biomass Carbon Ratio of Biopolyolefin.”

\section{Conflicts of Interest}

The authors declare no conflict of interest. 


\section{References}

1. Whitted, M.G.; Geher, J.F.; Benko, A.D.; Crvin, A.M.; Chotani, K.G.; Mcauliffe, C.J.; LaDuca, J.R.; Ben-Shoshan, A.E.; Sanford, J.K. Technology update: Development of a gas-phase bioprocess for isoprene-monomer production using metabolic pathway engineering. Ind. Biotechnol. 2010, 6, 152-163.

2. Bridgestone Official Web Site, News Release. Available online: http://www.bridgestone.com/ corporate/news/2012053101.html (accessed on 25 December 2013).

3. Van Beilen, B.J.; Poirier, Y. Guayule and Russian dandelion as alternative sources of natural rubber. Crit. Rev. Biotechnol. 2007, 26, 217-231.

4. Bridgestone Official Web Site, News Release. Available online: http://www.bridgestone.com/ corporate/news/2012051701.html (accessed on 25 December 2013).

5. The Japan Automobile Tyre Manufacturers Association, Tyre Industry of Japan 2013, Official Web Site. Available online: http://www.jatma.or.jp/media/pdf/tyre_industry_2013.pdf (accessed on 25 December 2013).

6. Stationary Source Emissions. Determination of the ratio of Biomass (Biogenic) and Fossil-Derived Carbon Dioxide-Radiocarbon Sampling and Determination, ISO 13833; ISO: Geneva, Switzerland, 20 March 2013.

7. Sumitomo Rubber Industries Official Web Site, News Release. Available online: http://www. srigroup.co.jp/english/ir/corporate/2013/2013_133.html (accessed on 25 December 2013).

8. Taguchi, K.; Kunioka, M.; Funabashi, M.; Ninoomiya, F. Estimation of biobased carbon content of polypropylene resin in composites based on carbon-14 concentration. J. Appl. Polym. Sci. 2014, doi:10.1002/app.39978.

9. Taguchi, K.; Kunioka, M.; Funabashi, M.; Ninoomiya, F. Biobased carbon content of resin extracted from polyethylene composite by carbon-14 concentration measurements using accelerator mass spectrometry. SpringerPlus 2014, doi:10.1186/2193-1801-3-6.

10. Japan BioPlastics Association Official Web Site. Available online: http://www.jbpaweb.net/ english/english.htm (accessed on 25 December 2013).

11. Japan Organic Recycling Association Official Web Site. Available online: http://www.jora.jp/txt/ katsudo/bm/index.html (accessed on 25 December 2013).

12. USDA BioPreferred Program Official Web Site. Available online: http://www.biopreferred.gov/ (accessed on 25 December 2013).

13. Association Chimie du Vegetal Official Web Site. Available online: http://www.chimiedu vegetal.com/en/ (accessed on 25 December 2013).

14. Kunioka, M. Measurement methods of biobased content for biomass-based chemicals and plastics. Radioisotopes 2013, 62, 901-925.

15. Funabashi, M.; Ninomiya, F.; Ohara, K.; Kunioka, M. Biomass carbon ratio of biomass chemicals measured by accelerator mass spectrometry. Bull. Chem. Soc. Jpn. 2009, 82, 1538-1547.

16. Kunioka, M. Possible incorporation of petroleum-based carbons in biochemicals produced by bioprocess. Appl. Microbiol. Biotechnol. 2010, 87, 491-497. 
17. Onishi, T.; Ninomiya, F.; Kunioka, M.; Funabashi, M.; Ohara, K. Biomass carbon ratio of polymer composites included biomass or petroleum origin resources. Polym. Degrad. Stabil. 2010, 95, 1276-1283.

18. Japan Rubber Manufacturers Association Official Web Site. Available online: http://www.jrma.gr.jp/ english.html (accessed on 25 December 2013).

19. Rubber-Identification-Infrared Spectrometry Method, ISO 4650; ISO: Geneva, Switzerland, 15 December 2012.

(C) 2014 by the authors; licensee MDPI, Basel, Switzerland. This article is an open access article distributed under the terms and conditions of the Creative Commons Attribution license (http://creativecommons.org/licenses/by/3.0/). 